\title{
Correction to: study and modeling of high-density polyethylene coalescence under the extrusion conditions
}

\author{
Abderrahmane Lamri ${ }^{1,2}$. Saad Lamouri ${ }^{1}$. Djamal Eddine Kherroub ${ }^{3} \cdot$ Said Lotfi Hafsaoui $^{1}$ • Farid Bakir ${ }^{4}$. \\ Abbas Tcharkhtchi ${ }^{2}$
}

Published online: 16 June 2020

(C) Springer-Verlag France SAS, part of Springer Nature 2020

\section{Correction to: International Journal of Material Forming} https://doi.org/10.1007/s12289-020-01567-8

The original publication of this article unfortunately contains error. The word "extrusion" was spelled incorrectly as "extrussion" in the article title.

Publisher's note Springer Nature remains neutral with regard to jurisdictional claims in published maps and institutional affiliations.

The online version of the original article can be found at https://doi.org/ $10.1007 / \mathrm{s} 12289-020-01567-8$

$\triangle$ Djamal Eddine Kherroub

djamaleddine.kherroub@yahoo.com;

kherroub.djamaleddine@edu.univ-oran1.dz

1 Ecole Militaire Polytechnique (EMP), Unité d'Etude et Recherche, des Procédés Energétiques (UERPE), Bordj-El-Bahri,

17 Algiers, BP, Algeria

2 Arts etMétiers ParisTech, PIMM-UMR CNRS 8006, 151 Boulevard de l'Hôpital, 75013 Paris, France

3 Laboratoire de Chimie des Polymères, Université d'Oran1 Ahmed Ben Bella, Oran, Algeria

4 DynFluid Lab - EA92, Arts et Métiers ParisTech, 151 Boulevard de l'Hôpital, 75013 Paris, France 